\title{
Pengaruh Corporate Social Responsibility Terhadap Nilai Perusahaan
}

\author{
Rifani Akbar Sulbahri \\ Jurusan Akuntansi, Universitas Tridinanti Palembang \\ Email: rifaniakbar.sulbahri@univ-tridinanti.ac.id
}

\begin{abstract}
This study aims to examine the effect of corporate social responsibility (CSR) on firm value. The analysis technique used is regression analysis Simple Based on the test results, the conclusions that can be drawn from this research arethat the results of the study indicate that the Corporate social responsibility variable has a significant effect on the value of the company with a value of prob. Corporate social responsibility variable < critical probability value $(a=5 \%)$ of $0.027<0.05$, so that the Corporate social responsibility variable has a significant effect on firm value. The conclusion is that corporate social responsibility has a significant effect on firm value in companies in the banking sub-sectoryears 2017-2019. The results show that partially Corporate social responsibility has a significant effect on firm value with a prob value. Corporate social responsibility variable $<$ critical probability value $(a=5 \%)$ of $0.027<0.05$, so that the Corporate social responsibility variable has a significant effect on firm value. The conclusion in the study accepts the hypothesis that corporate social responsibility has a significant effect on firm value.
\end{abstract}

Keywords: CSR, Company Value, Banking sub-sector

\begin{abstract}
ABSTRAK
Penelitian ini bertujuan untuk menguji pengaruh corporate social responsibility (CSR) terhadap nilai perusahaan. Teknik analisis yang digunakan adalah analisis regresi sederhana. Berdasarkan hasi lpengujian, maka kesimpulan yang dapat diambil dari penelitian ini adalah bahwa hasil penelitian menunjukkan bahwa variabel tanggung jawab sosial perusahaan berpengaruh signifikan terhadap nilai perusahaan dengan nilai prob .Variabel tanggung jawab sosial perusahaan < nilai probabilitas kritis $(\mathrm{a}=$ $5 \%$ ) sebesar 0,027 $<0,05$, sehingga variabel tanggung jawab sosial perusahaan berpengaruh signifikan terhadap nilai perusahaan. Kesimpulannya adalah bahwa tanggung jawab sosial perusahaan berpengaruh signifikan terhadap nilai perusahaan pada perusahaan sub sektor perbankan tahun 20172019. Hasil penelitian menunjukkan bahwa secara parsial tanggung jawab sosial perusahaan berpengaruh signifikan terhadap nilai perusahaan dengan nilai prob. Variabel tanggung jawab sosial perusahaan $<$ nilai probabilitas kritis $(a=5 \%)$ sebesar $0,027<0,05$, sehingga variabel tanggung jawab sosial perusahaan berpengaruh signifikan terhadap nilai perusahaan. Kesimpulan dalam penelitian ini menerima hipotesis bahwa tanggung jawab sosial perusahaan berpengaruh signifikan terhadap nilai perusahaan.
\end{abstract}

Kata kunci: CSR, Nilai Perusahaan, sub sektor perbankan 


\section{Pendahuluan}

Fenomena pengungkapan CSR sedang trend di banyak perusahaan terutama perusahaan besar. Pengungkapan CSR yang dilakukan perusahaan bermanfaat untuk meningkatkan citra, brand, dan harga saham perusahaan.

Pengungkapan CSR merupakan salah satu upaya yang dilakukan perusahaan untuk dapat memenuhi kepentingan stakeholder dan menjamin keberlangsungan perusahaan jangka panjang[1]. Penelitian yang dilakukan oleh [2] menyatakan bahwa tanggungjawab sosial perusahaan berpengaruh positif terhadap nilai perusahaan

Corporate Social Responsibility (CSR), merupakan wacana yang sedang mengemuka di dunia perusahaan multinational. Wacana ini digunakan oleh perusahaan dalam rangka mengambil peran menghadapi perekonomian menuju pasar bebas. Perkembangan pasar bebas yang telah membentuk ikatan-ikatan ekonomi dunia dengan terbentuknya AFTA, APEC dan sebagainya, telah mendorong perusahaan dari berbagai penjuru dunia untuk secara bersama melaksanakan aktivitasnya dalam rangka mensejahterakan masyarakat di sekitarnya. Perusahaan-perusahaan yang memiliki kepedulian sosial dapat menggunakan informasi tanggung jawab sosial (kegiatan CSR) sebagai salah satu keunggulan kompetitif perusahaan[3].

Epstein dan Freedman menemukan bahwa stakeholders tertarik terhadap informasi sosial yang dilaporkan dalam laporan tahunan, sehingga manajemen perusahaan tidak hanya dituntut terbatas atas pengelolaan dana yang diberikan, namun juga meliputi dampak yang ditimbulkan oleh perusahaan terhadap lingkungan alam dan sosial [4]. Tujuan utama perusahaan adalah untuk meningkatkan nilai perusahaan. Nilai perusahaan yang tinggi dapat meningkatkan kemakmuran bagi para pemegang saham, sehingga para pemegang saham akan menginvestasikan modalnya kepada perusahaan tersebut [5].

Menurut[6], sebuah teori yang melandasi pengungkapan CSR adalah teori legitimasi. Teori legitimasi merupakan suatu sistem yang mengutamakan kepentingan masyarakat atau lebih memihak kepada masyarat Pengungkapan CSR diharapkan dapat meningkatkan image perusahaan dan meningkatkan penjualan. Hal menunjukkan bahwa perusahaan yang menerapkan CSR berharap akan direspon positif oleh para pelaku pasar seperti investor dan kreditor yang nantinya dapat meningkatkan nilai perusahaan[7].

Menurut Basalamah dan Jermias dari sudut pandang ekonomi, perusahaan akan mengungkapkan suatu informasi jika informasi tersebut akan meningkatkan nilai perusahaan [8]. Menurut Kiroyan[7], perusahaan berharap jika dengan menerapkan Corporate Social Responsibility atau tanggung jawab sosial perusahaan akan memperoleh legitimasi sosial dan akan memaksimalkan ukuran keuangan untuk jangka waktu yang panjang. Hal ini menunjukkan bahwa perusahaan yang menerapkan Corporate Social Responsibility berharap akan direspon positif oleh para pelaku pasar seperti investor dan kreditur yang nantinya dapat meningkatkan nilai perusahaan.

Corporate Social Responsibility (CSR) adalah sebuah wacana yang menjadikan perusahaan tidak hanya berkewajiban atau beroperasi untuk pemegang saham (shareholders) saja namun juga mempunyai tanggung jawab sosial terhadap stakeholders. CSR sebagai bentuk pertanggungjawaban perusahaan terhadap lingkungan dan sosial dimana perusahaan tersebut berada. Pemikiran tersebut didasarkan pada 3P yaitu (profit, people, planet) menurut Global Compact Initiative 
yaitu tujuan perusahaan tidak hanya memburu keuntungan ekonomi (profit) namun juga untuk kesejahteraan orang (people), dan memiliki keperdulian terhadap kelestarian lingkungan hidup planet ini[9].

\section{LandasanTeori}

\section{Teori Agensi}

Teori keagenan (agency theory) menjelaskan bahwa hubungan agensi muncul ketika satu orang atau lebih (principal) mempekerjakan orang lain (agent) untuk memberikan suatu jasa dan kemudian mendelegasikan wewenang pengambilan keputusan kepada agent tersebut[10]. Sedangkan[11] menyatakan agen menutup kontrak untuk melakukan tugas-tugas tertentu bagi prinsipal dan prinsipal menutup kontrak untuk memberi imbalan kepada agen. Analoginya seperti antara pemilik perusahaan dan manajemen perusahaan.

\section{Legitimacy Theory}

Menurut Haniffa et al., [7], dalam legitimacy theory perusahaan memiliki kontrak dengan masyarakat untuk melakukan kegiatannya berdasarkan nilai-nilai justice, dan bagaimana perusahaan menanggapi berbagai kelompok kepentingan untuk melegitimasi tindakan perusahaan. Oleh karena itu perusahaan semakin menyadari bahwa kelangsungan hidup perusahaan juga tergantung dari hubungan perusahaan dengan masyarakat dan lingkungan dimana perusahaan tersebut menjalankan setiap aktivitasnya.

\section{Corporate Social Responsibility (CSR)}

MenurutThe World Business Council for Sustainable Development(WBCSD)dalam [12],Corporate SocialResponsibilityatau tanggung jawab sosial perusahaan didefinisikan sebagaikomitmen bisnis untuk memberikan kontribusi bagi pembangunan ekonomi berkelanjutan,melalui kerja sama dengan para karyawan serta perwakilan mereka, keluarga mereka,komunitas setempat maupun masyarakat umum untuk meningkatkan kualitas kehidupandengan cara yang bermanfaat baik bagi bisnis sendiri maupun untuk pembangunan.Konsep Corporate Social Responsibilitymelibatkan tanggung jawab kemitraan antarapemerintah, lembaga sumberdaya masyarakat, serta komunitas setempat (lokal). Kemitraanini tidaklah bersifat pasif dan statis. Kemitraan ini merupakan tanggung jawab bersamasecara sosialantarastakeholders.Pertanggungjawaban sosial perusahaan diungkapkan di dalam laporan yang disebut Sustainibility Reporting. Sustainibility Reporting adalah pelaporan mengenai kebijakan ekonomi, lingkungan dan sosial, pengaruh dan kinerja organisasi dan produknya di dalam konteks pembangunan berkelanjutan (sustainable development).Sustainibility Reporting harus menjadi dokumen strategis yang berlevel tinggi yang menempatkan isu, tantangan dan peluang Sustainibility Developmenty ang membawanya menuju kapada core business dan sektor industrinya.

\section{Nilai Perusahaan}

Tujuan utama perusahaan adalah untuk meningkatkan nilai perusahaan melalui peningkatan kemakmuran pemilik atau para pemegang saham[13]. Nilai perusahaan pada dasarnya diukur dari beberapa aspek salah satunya adalah harga pasar saham 
perusahaan, karena harga pasar saham perusahaan mencerminkan penilaian investor atas keseluruhan ekuitas yang dimiliki [14][14]. Menurut [15] "Value is respresented by the market price of the company's commom stock which in turn, is afunction of firm's investement, financing and dividend decision." Harga pasar saham menunjukkan penilaian sentral di semua pelaku pasar, harga pasar saham merupakan barometer kinerja perusahaan.Menurut[16], nilai perusahaan didefinisikan sebagai nilai pasar. Alasannya karena nilai perusahaan dapat memberikan kemakmuran atau keuntungan bagi pemegang saham secara maksimum jika harga saham perusahaan meningkat. Semakin tinggi harga saham, maka makin tinggi keuntungan pemegang saham sehingga keadaan ini akan diminati oleh investor karena dengan permintaan saham yang meningkatkan menyebabkan nilai perusahaan juga akan meningkat. Nilai perusahaan dapat dicapai dengan maksimum jika para pemegang saham menyerahkan urusan pengelolaan perusahaan kepada orang-orang yang berkompeten dalam bidangnya, seperti manajer maupun komisaris.Rasio-rasio keuangan digunakan investor untuk mengetahui nilai pasar perusahaan. Rasio tersebut dapat memberikan indikasi bagi manajemen mengenai penilaian investor terhadap kinerja perusahaan dimasa lampau dan prospeknya dimasa depan. Ada beberapa rasio untuk mengukur nilai pasar perusahaan, salah satunya Tobin's Q. Rasio ini dinilai bisa memberikan informasi paling baik, karena dalam Tobin's Q memasukkan semua unsur hutang dan modal saham perusahaan, tidak hanya saham biasa saja dan tidak hanya ekuitas perusahaan yang dimasukkan namun seluruh asset perusahaan. Dengan memasukkan seluruh asset perusahaan berarti perusahaan tidak hanya terfokus pada satu tipe investor saja yaitu investor dalam bentuk saham namun juga untuk kreditur karena sumber pembiayaan operasional perusahaan bukan hanya dari ekuitasnya saja tetapi juga dari pinjaman yang diberikan oleh kreditur [17]. [8] menyimpulkan bahwa tobin's Q dapat digunakan sebagai alat ukur dalam menentukan nilai perusahaan.

\section{Kerangka Berpikir}

\section{Gambar 1}

\section{Kerangka Pemikiran}
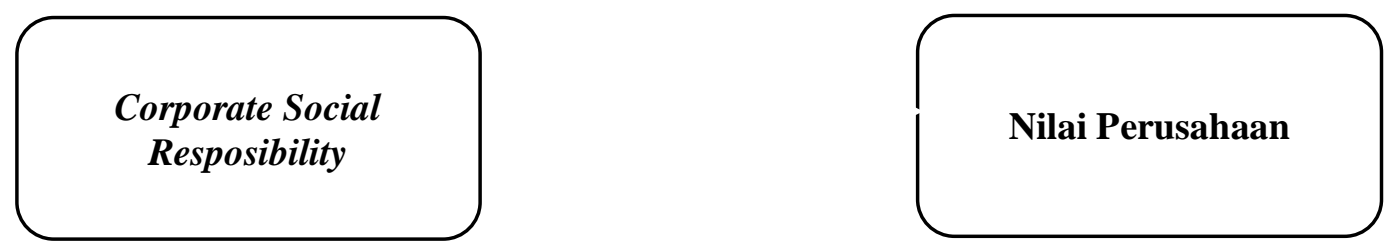

Berdasarkan gambar di atas maka Corporate social responsibility akan dianalisis pengaruhya terhadap nilai perusahaan.Berdasarkan landasan teori dan berdasarkan kerangka pemikiran maka hipotesis dari penelitian ini adalah sebagai berikut:

\section{PengembanganHipotesis}

Hipotesis dalam penelitian ini adalah sebagai berikut: Berdasarkan teori stakeholder dan teori legitimasi yang menjelaskan kaitan laporan CSR pada nilai perusahaan. Teori ini baik secara langsung maupun tidak langsung menjelaskan kontrak dan kewajiban perusahaan pada lingkungan disekitarnya. Kemudian teori ini juga didukung penelitian 
sebelumnya yang dilakukan oleh [2],[16],menyatakan bahwa pengungka pantanggungjawab sosial perusahaan berpengaruh positif terhadap nilai perusahaan. Berdasarkan teori dan hasil penelitian tersebut atas, maka dapat dirumuskan hipotesis sebagai berikut.

H1 : Corporate social responsibility berpengaruh terhadap Nilai Perusahaan

\section{Metodologi Penelitian}

\section{Sumber dan Teknik pengumpulan data}

\section{a. Sumber Data}

Sumber data yang digunakan dalam penelitian ini ialah data sekunder yaitu laporan keuangan perusahaan Perbankan periode 2017-2019 dari website www.idx.co.id

\section{b. Teknik Pengumpulan Data}

Penelitian ini menggunakan teknik pengumpulan data dokumentasi, yaitu peneliti melakukanpengumpulan data yang diperoleh melalui dokumen-dokumen atau data yang diperoleh secaratidak langsung atau melalui media perantara yaitu internet melalui situs bursa efek indonesiadengan melihat laporan keuangan yang diterbitkan setiap tahunnya baik salam media cetak maupun data yang didwonload dari internet melalui www.idx.co.id.

\section{Metode Analisis Data}

Teknik analisis kuantitatif dalam penelitian ini menggunakan data laporan keuangan untukmeneliti pada populasi atau sampel tertentu dengan analisis data yang ada, analisis ini jugadilakukan dengan menggunakan program komputer yaitu SPSS.

\section{Sampel}

Sampel yang dipilih dalam penelitian ini adalah perusahaan sub sektor perbankan di BEI dengan kriteria sebagai berikut:

a) Saham perusahaan yang masih aktif yang terdaftar di BEI selama periode 20172019.

b) Perusahaan sub sektor perbankan yang menyajikan laporan keuangan dan rasio secara lengkap sesuai dengan variabel yang akan diteliti berdasarkan sumber yang digunakan.

c) Perusahaantelah mempublikasikan laporan keuangan yang telah diaudit pada periode 2017-2019.

\section{Teknik Analisis Data}

Dalam penelitian ini, teknik analisis data menggunakan alat bantu statistik SPSS,dengan melakukan pengujian Uji Asumsi Klasik, Uji Heteroskedastisitas, Uji Multikolinieritas, Analisis Regresi Sederhana, Signifikanasi Parsial (uji t), dan Koefisien Determinasi ( R. ${ }^{2}$ ) 


\section{HasilPenelitiandanPembahasan}

\section{Gambaran Umum Penelitian}

Analisis penelitian ini menggunakan data sekunder yang bersumber dari laporan keuangan tahunan pada perusahaan Perbankan yang dipublikasikan dan terdaftar di Bursa Efek Indonesia (BEI) dengan rentang waktu 2017-2019. Data tersebut diambil dari situs www.idx.co.id. Adapun perusahaan yang digunakan dalam penelitian ini adalah sebagaiberikut :

\section{Tabel 1}

\section{DaftarNama Bank yang terdaftar di Bursa Efek Indonesia}

\begin{tabular}{|c|c|l|}
\hline No & Kode & \multicolumn{1}{c|}{ Nama Bank } \\
\hline 1 & BBCA & Bank Central Asia Tbk \\
\hline 2 & BBNI & Bank Negara Indonesia Tbk \\
\hline 3 & BBRI & Bank Rakyat Indonesia Tbk \\
\hline 4 & BBTN & Bank Tabungan Negara Tbk \\
\hline 5 & BDMN & Bank Danamon \\
\hline 6 & BJBR & $\begin{array}{l}\text { Bank Pembangunan Daerah Jawa Barat Dan } \\
\text { Banten }\end{array}$ \\
\hline 7 & BJTM & Bank Pembangunan Daerah Jawa Timur \\
\hline 8 & BMAS & Bank Maspion \\
\hline 9 & BMRI & Bank Mandiri Tbk \\
\hline 10 & BNGA & Bank CIMB Niaga \\
\hline 11 & MAYA & Bank Mayapada \\
\hline 12 & MEGA & Bank Mega \\
\hline 13 & NISP & Bank OCBC NISP \\
\hline 14 & PNBN & Bank PAN Indonesia \\
\hline
\end{tabular}

Sumber : www.idx.co.id, Data diolah 2021

\section{Statistik Deskriftif}

Analisis statistik deskriptif digunakan untuk memberikan gambaran umum dari data yang digunakan. Tabel 2 menunjukan statistik deskriptif masing-masing variabel yang digunakan dalam penelitian berupa variabel independen yaitu Corporate Social Responsibility,dan variabel dependen Nilai perusahaan. Variabel-variabel penelitian tersebut diinterprestasikan dalam nilai mean, median, maximum, minimum. Jumlah pengamatan pada penelitian yaitu 42 data dan merupakan gabungan dari 14 perusahaan perbankan dengan rentang waktu selama tahun 2017-2019. Hasil analisis statistik deskriftif dapat dilihat pada tabel dibawah :

\section{Tabel 2}

Descriptive Statistics

\begin{tabular}{|c|c|c|c|c|c|c|c|}
\hline & $\mathrm{N}$ & Range & Minimum & Maximum & \multicolumn{2}{|c|}{ Mean } & $\begin{array}{c}\text { Std. } \\
\text { Deviation }\end{array}$ \\
\hline & Statistic & Statistic & Statistic & Statistic & Statistic & Std. Error & Statistic \\
\hline $\begin{array}{l}\text { Corporate Social } \\
\text { Responsibility }\end{array}$ & 42 & .240 & .304 & .544 & .47536 & .009644 & .062499 \\
\hline Nilai Perusahaan & 42 & .87340 & .83385 & 1.70725 & 1.0767648 & .03192379 & .20688982 \\
\hline Valid N (listwise) & 42 & & & & & & \\
\hline
\end{tabular}


Deskripsi dari masing-masing variabel berdasarkan tabel tersebut, yaitu :

a) Variabel dependen nilai perusahaan (Tobinsq) memiliki nilai tertinggi sebesar 1.707 dimiliki oleh Bank Central Asia Tbk pada tahun 2019 dan terendah sebesar 0.833 dimiliki olehBank Rakyat Indonesia Tbk pada tahun 2017. Nilai mean dan range pada variabel nilai perusahaan masing-masing sebesar 1.076 dan 0.873. Adapun standar deviasi nilai perusahaan sebesar 0.206 .

b) Variabel independen corporate social responsibility memiliki nilai tertinggi sebesar 0.544 dimiliki oleh Bank Mega Tbk pada tahun 2019 dan terendah sebesar 0.304 dimiliki oleh Bank Rakyat Indonesia Tbk pada tahun 2017-2019. Nilai mean dan range pada variabel corporate social responsibility masing-masing sebesar 0.475dan 0.240. Adapun standar deviasi corporate social responsibilitysebesar 0.624 .

\section{Uji Asumsi Klasik}

\section{UjiNormalitas}

Tabel 3

UjiNormalitas

\begin{tabular}{|c|c|c|}
\hline \multicolumn{3}{|c|}{ One-Sample Kolmogorov-Smirnov Test } \\
\hline & & $\begin{array}{c}\text { Unstandardized } \\
\text { Residual }\end{array}$ \\
\hline $\mathrm{N}$ & & 42 \\
\hline \multirow[t]{2}{*}{ Normal Parametersa,b } & Mean & .0000000 \\
\hline & Std. Deviation & .20384448 \\
\hline \multirow[t]{3}{*}{ Most Extreme Differences } & Absolute & .250 \\
\hline & Positive & .250 \\
\hline & Negative & -.167 \\
\hline Test Statistic & & .250 \\
\hline Asymp. Sig. (2-tailed) & & $.306^{c}$ \\
\hline
\end{tabular}
a. Test distribution is Normal.
b. Calculated from data.
c. Lilliefors Significance Correction.

Pada tabel di atas dapat dilihat nilai csr (Asymp. Sig. (2-tailed))sebesar 0,306 karena nilai pada uji kolmogrov-smirnov masih lebihbesar dari tingkat kekeliruan 5\% $(0,05)$,maka dapat disimpulkan bahwa model regresi penelitian berditribusi dengan normal. 


\section{Uji Heteroskedastisitas}

\section{Tabel 4}

\section{Uji Heteroskedastisitas}

Coefficients ${ }^{\mathbf{a}}$

\begin{tabular}{|c|c|c|c|c|c|c|}
\hline \multirow{2}{*}{\multicolumn{2}{|c|}{ Model }} & \multicolumn{2}{|c|}{$\begin{array}{c}\text { Unstandardized } \\
\text { Coefficients }\end{array}$} & \multirow{2}{*}{$\begin{array}{c}\text { Standardized } \\
\text { Coefficients } \\
\text { Beta } \\
\end{array}$} & \multirow[b]{2}{*}{$\mathrm{t}$} & \multirow[b]{2}{*}{ Sig. } \\
\hline & & $\mathrm{B}$ & Std. Error & & & \\
\hline \multirow[t]{2}{*}{1} & (Constant) & .267 & .176 & & 1.515 & .138 \\
\hline & $\begin{array}{l}\text { Corporate Social } \\
\text { Responsibility }\end{array}$ & -.267 & .368 & -.114 & -.726 & .472 \\
\hline
\end{tabular}

a. Dependent Variable: res2

Berdasarkan pada tabel di atas dapatdilihat bahwa nilai signifikan (Sig) untukvariabel bebas Corporate Social Responsibility sebesar 0,472 dikarenakan nilai signifikan dari koefisien variabel bebas dari 0,05, maka dapat disimpulkan bahwa persamaan regresi yang digunakan dalam penelitian ini tidak mengalami heteroskedasitas.

\section{Uji Multikolinieritas}

Tabel 5

\section{Uji Multikolinieritas}

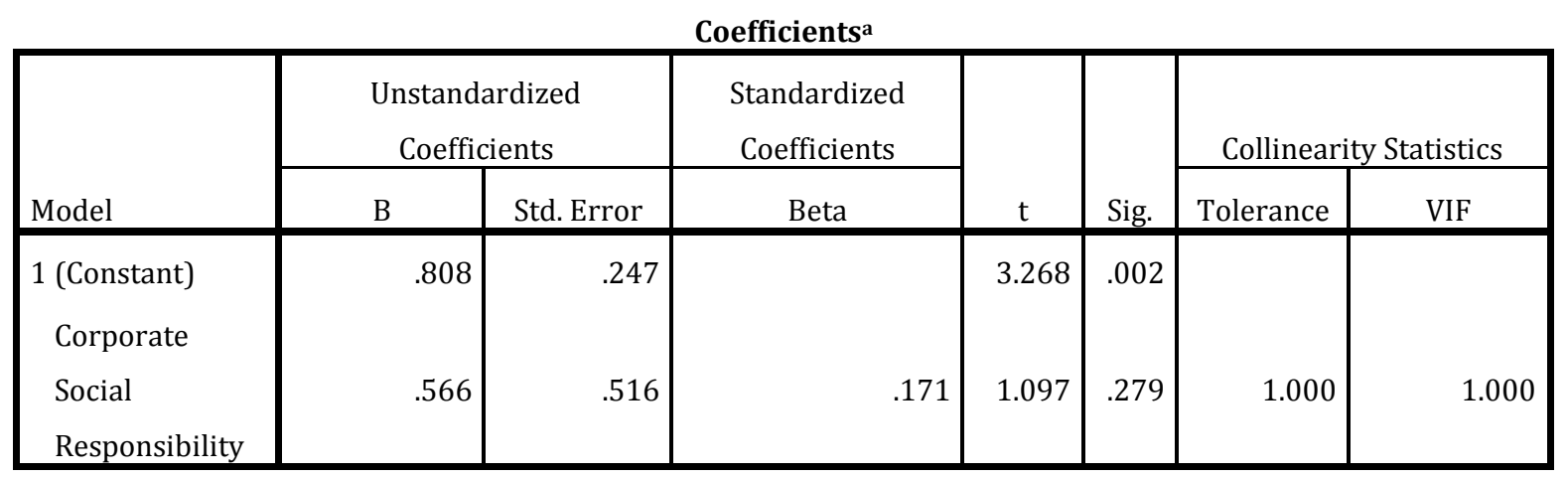

a. Dependent Variable: Nilai Perusahaan

Berdasarkan tabel di atas, menunjukan bahwa nilai corporate social responsibility sebesar1.000 dimana nilai tolerance ketiga vaiabel bebas lebih besar dari dari nilai 0,1. Sedangkan nilai VIF dari variabel corporate social responsibility masing-masing sebesar 1.000 dimana nilai VIF variabel bebas lebih kecil dari nilai 10. Dikarenakan nilai variabel bebas dalam penelitian ini memiliki tolerance value $>0,1$ dan VIF $<10$, maka dapat disimpulkan bahwa ketiga variabel bebas tersebut tidak terdapat hubungan multikoliniearitas. 


\section{Uji Regresi Sederhana}

\section{Tabel 6}

UjiRegresiSederhana

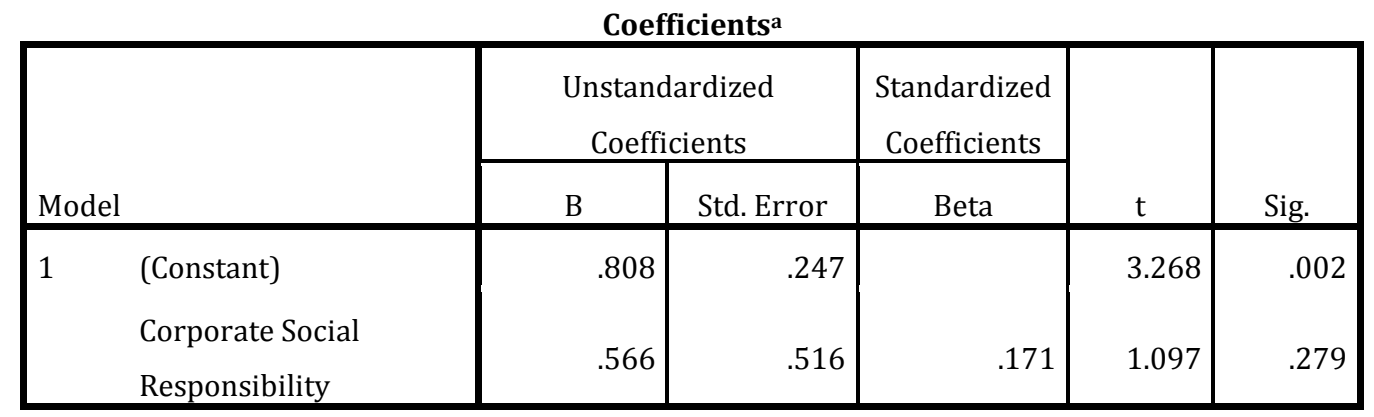

a. Dependent Variable: Nilai Perusahaan

Dari tabel diatas diperoleh hasilmodel regresi linear berganda sebagai berikut $\mathrm{Y}=\mathrm{a}+\mathrm{bx}$ $\mathrm{Y}=0.808+5,66$ CSR Dari persamaan diatas dapat dijelaskan sebagai beikut:

1. Konstanta (a) sebesar 0.808 , artinya jika variabel indenpenden yaitu CSR (X1), diasumsikan bahwa konstan, maka variabel dependen Nilai perusahaan (Y) akan meningkat $0.808 \%$

2. Koefisien Regresi $X$ sebesar 0.566 menyatakan bahwa setiap penambahan $1 \%$ nilai Corporate Social Responsibility, maka nilai perusahaan bertambah sebesar 0.566. Koefisien regresi tersebut bernilai positif, sehingga dapat dikatakan bahwa arah pengaruh variabel corporate social responsibility terhadap Nilai Perusahaan adalah Positif.

\section{Uji T Statistik}

Menurut [18][18], uji t pada dasarnya memiliki tujuan untuk menunjukkan seberapa jauh pengaruh suatu variabel penjelas atau independen secara individual dalam menerangkan variabel independen. Kriteria pengujian yang dilakukan adalah:

a) Jika nilai prob. = a (0.05) maka Ha diterima Hal ini berarti ada pengaruh yang signifikan dari variabel independen terhadap variabel dependen.

b) Jika nilai prob = a (0.05) maka $\mathrm{H} 0$ diterima Hal ini berarti tidak ada pengaruh yang signifikan dari variabel independen terhadap variabel dependen. Hasil uji t pada penelitian ini dapat dilihat pada tabel berikut :

\section{Tabel 7}

Uji T

\begin{tabular}{|c|c|c|c|c|c|c|}
\hline \multicolumn{7}{|c|}{ Coefficients ${ }^{a}$} \\
\hline \multirow{2}{*}{\multicolumn{2}{|c|}{ Model }} & \multicolumn{2}{|c|}{$\begin{array}{c}\text { Unstandardized } \\
\text { Coefficients }\end{array}$} & \multirow{2}{*}{$\begin{array}{c}\text { Standardized } \\
\text { Coefficients } \\
\text { Beta }\end{array}$} & \multirow[b]{2}{*}{$\mathrm{t}$} & \multirow[b]{2}{*}{ Sig. } \\
\hline & & $\mathrm{B}$ & Std. Error & & & \\
\hline 1 & (Constant) & .420 & .052 & & 8.138 & .000 \\
\hline & Nilai Perusahaan & .052 & .047 & .171 & 1.097 & 0.027 \\
\hline
\end{tabular}

a. Dependent Variable: Corporate Social Responsibility 
Berdasarkan tabel diatas, maka:

$\mathrm{H} 1=$ (Corporate social responsibilityberpengaruh signifikan terhadap Nilai perusahaan) Nilai prob. variabel Corporate social responsibility< nilai probabilitas kritis $(a=5 \%)$ sebesar $0.027<0,05$, sehingga variabel Corporate social responsibility berpengaruh signifikan terhadap nilai perusahaan. Kesimpulan pada penelitian menerima H1 artinya CSR berpengaruh signifikan terhadap Nilai perusahaan.

\section{Koefisien Determinasi ( $\mathbf{R}^{2}$ )}

[18] menyatakan bahwa koefisien determinasi (Rsquared) mengukur seberapa jauh kemampuan model dalam menerangkan variasi variabel dependen. Nilai koefisien determinasi berkisar nol sampai satu. Nilai R-squared yang kecil berarti kemampuan variabel-variabel independen dalam menjelaskan variasi variabel dependen amat terbatas. Hasil koefisien determinasi dapat dilihat pada tabel berikut:

\section{Tabel 8}

\section{KoefisienDeterminasi}

\begin{tabular}{|l|r|r|r|c|}
\hline & & & \multicolumn{1}{|c|}{ Model Summary } \\
Model & $\mathrm{R}$ & $\mathrm{R}$ Square & \multicolumn{1}{c|}{$\begin{array}{c}\text { Square } \\
\text { R }\end{array}$} & $\begin{array}{c}\text { Std. Error of the } \\
\text { Estimate }\end{array}$ \\
\hline 1 & $.171^{\mathrm{a}}$ & .029 & .005 & .20637680 \\
\hline
\end{tabular}

a. Predictors: (Constant), Corporate Social Responsibility

Dari output diatas, didapatkan nilai Adjusted R Square (koefisien Determinasi) sebesar 0.005 yang artinya pengaruh variabel independent $(\mathrm{X})$ terhadap variabel dependent $(\mathrm{Y})$ Sebesar 5\%.

\section{Pembahasan}

Penelitian ini bertujuan untuk meneliti pengaruh Corporate social responsibility (CSR)terhadap nilai perusahaan. Teknik analisis yang digunakan adalah Analisis Regresi sederhana yaitu sebuah metode pendekatan untuk permodelan hubungan antara satu variabel dependen dan satu variabel independen. Dalam model regresi, variabel independen menerangkan bahwa variabel dependennya. Pada penelitian ini hasil penelitian menunjukan bahwa variabel Corporate social responsibilityberpengaruh signifikan terhadap Nilai perusahaan dengan Nilai prob. variabel Corporate social responsibility< nilai probabilitas kritis $(a=5 \%)$ sebesar $0.027<0,05$, sehingga variabel Corporate social responsibility berpengaruh signifikan terhadap nilai perusahaan. Untuk menambah referensi penelitian selanjutnya, ada beberapa saran yang dikemukakan sebagai berikut:

1. Penelitian selanjutnya perlu mempertimbangkan sampel yang lebih luas. Hal ini dimaksudkan agar kesimpulan yang dihasilkan dari peneliti tersebut memiliki cakupan yang lebih luas.

2. Item pengungkapan tanggung jawab sosial perusahaan hendaknya senantiasa di perbaharui sesuai dengan kondisi yang ada di masyarakat. 


\section{Kesimpulan dan Saran}

Fenomena yang diperoleh dan hasil uji secara empiris yang telah dilakukan faktor-faktor yang mempengaruhi nilai suatu perusahaan adalah pengungkapan CSR. Hasil penelitian menunjukan pengaruh pengungkapan CSR berpengaruh positif terhadap nilai perusahaan pada perusahaan perbankan di Indonesia. Penelitian ini juga memberikan bukti empiris yang mendukung teori stakeholder, legitimasi, keagenan, teori sinyal dan beberapa hasil penelitian sebelumnya. Semakin banyak perusahaan melakukan CSR, maka semakin tinggi citra atau nilai perusahaan tersebut. Berdasarkan simpulan maka saran penelitian adalah pengungkapan CSR di Indonesia yang masih kurang sebaiknya ditingkatkan, bagi perusahaan yang konsisten melakukan dan mengungkapkan CSR yang bermanfaat bagi masyarakat sebaiknya memberikan penghargaan yang sesuai sehingga memberikan rangsangan bagi perusahaan yang belum melakukan CSR. Saran penelitian yang lain bisa menggunakan proksi yang lain yang bisa menghasilkan hasil yang konsisten. masih banyak variabel lain yang mempengaruhi nilai perusahaan sehingga perlu dicari fenomena lain yang dapat mempengaruhi nilai perusahaan. Dan bisa saja dengan menambah variabel intervening atau moderasi yang sesuai dengan perkembangan saat ini.

\section{Referensi}

[1] Y. Atmaja, VERONIKA, FATAHURRAZAK, and T. MANIK, "Pengaruh Corporate Social Responsibility Terhadap Kinerja Keuangan Dengan Kepemilikan Asing Sebagai Variabel Moderator Pada Perusahaan Industri Barang Konsumsi Yang Terdaftar Di Bursa Efek Indonesia Periode 2013-2015," vol. 6, no. 4, pp. 1-8, 2015.

[2] Putri, "Pengaruh Pengungkapan C orporate Social Responsibility pada Nilai Perusahaan dengan Manajemen Laba sebagai Variabel Moderasi," vol. 14, no. 1, pp. 56-69, 2016.

[3] Zuhroh and Sukmawati, "Analisis Pengaruh Luas Pengungkapan Sosial dalam Laporan Tahunan Perusahaan terhadap Reaksi Investor (Studi Kasus pada Perusahaanperusahaan High Profile di BEJ)," Simp. Nas. Akunt., vol. VI, no. 1, pp. 38-42, 2008.

[4] M. J. Epstein and M. Freedman, "Social Disclosure and the Individual Investor," Accounting, Audit. Account. J., vol. 7, no. 1, pp. 23-27, 2007.

[5] T. Haruman, "Pengaruh Struktur Kepemilikan Terhadap Keputusan Keuangan dan Nilai Perusahaan Survey Pada Perusahaan Manufaktur di PT. Bursa Efek Indonesia," Univ. Widyatama, 2008.

[6] Gray, Pengantar Evaluasi Proyek. Jakarta: Gramedia Pustaka Utama, 1995.

[7] Y. Sayekti and L. S. Wondabio, "Pengaruh CSR Disclosure Terhadap Earning Response Coefficient,” 2007.

[8] A. S. Basalamah and J. Jermias, "Social and Environmental Reporting and Auditing in Indonesia: Maintaining Organizational Legitimacy?," Gadjah Mada Int. J. Bus., 2005, doi: 10.22146/gamaijb.5565.

[9] Y. Nugroho, "Tanggungjawab dan Keberlanjutan," 2005. .

[10] W. H. Jensen, M. C., \& Meckling, Theory of the Firm: Managerial Behavior, Agency Costs and Ownership Structure. Journal of Financial Economics. 1976. 
[11] E. S. Hendriksen and M. Brenda, Teori Akunting, 5th ed. Batam: Interaksara, 2000.

[12] Solihin, "Pengaruh Indikator Good Corporate Governance Dan Profitabilitas Pada Pengungkapan Corporate Social Responsibility," E-Jurnal Akunt., vol. 3, no. 3, pp. 65-82, 2008.

[13] Wahidawati, "Pengaruh Kepemilikan Manajerial dan Kepemilikan Institusional pada Kebijakan Hutang Perusahaan: Sebuah Perspektif Theory Agency," J. Ris. Akunt. Indones., vol. 5, no. 1, pp. 1-16, 2002.

[14] U. Wahyudi and H. P. Prasetyaning, "Implikasi Struktur Kepemilikan Terhadap Nilai Perusahaan: Dengan Keputusan Keuangan Sebagai Variabel Intervening," 2006.

[15] P. Diyah and E. Widanar, "Pengaruh Struktur Kepemilikan Terhadap Nilai Perusahaan: Keputusan Keuangan sebagai Variabel Intervening," J. Ekon. Bisnis dan Akunt. Ventur., vol. 12, no. 1, pp. 71-86, 2009.

[16] R. Nurlela and Islahuddin, "Pengaruh Corporate Social Responsibilityterhadap Nilai Perusahaan dengan Prosentase kepemilikan Menejerial sebagai Variabel Moderating," 2008.

[17] S. Sukamuja, "Good Corporate Governance di Sektor Keuangan: Dampak GCG Terhadap Kinerja Perusahaan (Kasus di Bursa Efek Jakarta)," BENEFIT, vol. 8, no. 1, pp. 1-25, 2004.

[18] I. Ghozali and D. Ratmono, "Analisis Multivariat dan Ekonometrika: Teori, KOnsep, dan APlikasi dengan EViews 10), Semarang: Badan Penerbit-Undip," text Ref., 2018. 